\title{
家族システムの発達と移行に関する研究 (4)
}

\author{
地域生活満足度および居住継続意図への影響要因の検討

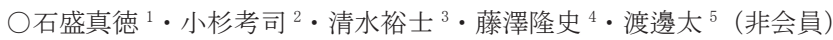 \\ $\left({ }^{1}\right.$ 追手門学院大経営学部・ ${ }^{2}$ 山口大教育学部・ ${ }^{3}$ 関学大社会学部・ ${ }^{4}$ 福井大子どものこころの発達研究センター・ ${ }^{5}$ 大阪国際大人間科学部 $)$ \\ キーワード : 家族システム論、コミュニティ意識、生活満足度
}

\begin{abstract}
The development and transition of families in Japan from the family systems theory perspective (4) Masanori ISHIMORI ${ }^{1}$, Koji KOSUGI ${ }^{2}$, Hiroshi Shimizu ${ }^{3}$, Takashi FUJISAWA ${ }^{4}$, and Futoshi WATANABE,\# ( ${ }^{1}$ Otemon Gakuin Univ., ${ }^{2}$ Yamaguchi Univ., ${ }^{3}$ Kwansei Gakuin Univ., ${ }^{4}$ Fukui Univ., ${ }^{5}$ Osaka International Univ.)
\end{abstract}

Key Words: family systems theory, sense of community, life satisfaction

\section{目 的}

本研究では、家族システムの発達と移行について明らかに することを目的として、子育て期を終了する前後の家族に属 する夫婦を対象に調査を実施した。

\section{方 法}

調査は 2012 年 11 月から 12 月にかけて、東海地方在住の イプソス株式会社の調査モニターを対象にインターネット調 查で実施した。調査時点で家族成員全員が同居しており、か つ末が高校生の 4 人家族の父親と母親を調查対象とした。 223 組の夫婦 (夫の平均年齢 49.7 歳、妻の平均年齢 47.1 歳) から有効な調査の回答が得られた。用いた調査項目は、年 齢・職業・学歴等のデモグラフィック要因に関わる 16 項 目、コミュニティ意識尺度短縮版 12 項目 (5 件法、石盛・岡 本・加藤，2013）、「居住継続意図・地域生活満足度」など地 域での生活に関する 8 項目 (5 件法)、地域の現状認識に関す る 5 項目 (5 件法)、地域特性の測定項目 12 項目 (5 件法、柴 内，2010）、FACESIII 日本語版の凝集性 10 項目 ・適応性 10 項 目 (5 件法、草田 - 岡堂，1993)、身体的 - 精神的健康尺度 9 項目 (4 件法、諸井, 1996)、主観的幸福感尺度 3 項目 (4 件 法、伊藤他，2003）、子どもとの会話で話題として話す程度 を測定する 7 項目 (4 件法)、夫婦間の問題への対処方略尺度 の下位尺度のうち「積極的アプローチ」5 項目と「回避」5 項目 (5 件法、野澤，2008)等であった。

\section{結果と考察}

コミュニティ意識と地域の現状認識に関する男女差を検討 するために $t$ 検定を行った。その結果、表 1 の通りコミュニ ティ意識の他者依頼、地域の結びつき、地域の熟知、地域の あいさつ・マナー、および地域での参加交流において有意差 が見られ、すべての項目の平均值で女性の平均值が高かっ た。男性よりも女性のほうが地域の現状についてポジティブ に評価し、かつ積極的に参加交流している一方で、他者依頼 の意識が強いという結果であった。

表1 コミュニティ意識と地域の現状認識に関する男女の平均値

\begin{tabular}{lll}
\hline & 男性 & 女性 \\
\hline 連帯·積極性 & 2.73 & 2.78 \\
自己決定 & 3.41 & 3.44 \\
他者依頼 & 3.06 & $3.18^{*}$ \\
愛着 & 3.14 & $3.10^{*}$ \\
地域の結びつき & 2.87 & $3.02^{*}$ \\
地域の活動レベル & 3.00 & $3.12^{*}$ \\
地域の熟知 & 2.51 & $2.68^{*}$ \\
地域のあいさつ·マナー & 3.13 & $3.32^{* *}$ \\
地域での参加交流 & 2.60 & $2.91^{* *}$ \\
地域での孤独·孤立 & 2.24 & 2.22 \\
\hline
\end{tabular}

${ }^{*} p<.05 ;{ }^{* *} p<.01$
次に、地域生活満足度に影響する要因を検討するために、 生活満足度を従属変数、性別 (男性 $=0$ 、女性 $=1$ とするダミ 一変数)、地域の現状認識に関する項目、コミュニティ意 識、身体的・精神的健康尺度等の心理尺度の下位因子を説明 変数とする重回帰分析をステップワイズ法により行った。そ の結果、表 2 の通り、愛着、家族の柔軟性、地域の結びつき がそれぞれ正の、うつと性別がそれぞれ負の有意な影響を有 していた。地域コミュニティへの愛着が高く、地域の結びつ きを強く認識し、家族の柔軟性が高いほど地域生活満足度が 高く、逆にうつ傾向が高いほど、また男性よりも女性の方 が、生活満足度が低いという結果であった。

表2 地域生活満足度を従属変数とする重回帰分析結果

\begin{tabular}{lc}
\hline \multicolumn{1}{c}{ 説明変数 } & $\beta$ \\
\hline 愛着 & $.388^{* *}$ \\
うつ & $-.174^{* *}$ \\
家族の柔軟性 & $.135^{* *}$ \\
地域の結びつき & $.112^{*}$ \\
性別ダミ一 & $-.083^{*}$ \\
\hline \multicolumn{1}{c}{$R^{2}$} & $.323^{* *}$ \\
\hline${ }^{* *}{ }_{p<01}{ }^{*} p<05$ &
\end{tabular}

同様の方法で、居住継続意図を従属変数とする重回帰分析 を行った結果、表 3 の通り、愛着、積極的アプローチ、家族 の柔軟性が正の、地域での孤独・孤立と子どもとの会話が負 の有意な影響を及ぼしていた。この結果は、地域コミュニテ イへの愛着が高く、夫婦間の問題に積極的アプローチを取る 傾向にあるほど、また、家族の柔軟性が高いほど居住継続意 図が強くなるということを示していた。逆に、地域での孤 独・孤立の高さと子どもとの会話の多さは居住継続意図を低 めるという影響を及ぼしていた。

地域生活満足度と居住継続意図に家族の柔軟性という家族 関係に関する要因が共通して影響を及ぼしていた点は、家族 のあり方と地域コミュニティとの関連性についてより詳細な 検討の必要性を示唆する結果といえる。

表3 居住継続意図を従属変数とする重回帰分析結果

\begin{tabular}{cc}
\hline \multicolumn{1}{c}{ 説明変数 } & $\beta$ \\
\hline 愛着 & $.456^{* *}$ \\
地域での孤独·孤立 & $-.187^{* *}$ \\
積極的アプロ一チ & $.109^{* *}$ \\
子どもとの会話 & $-.134^{* *}$ \\
家族の柔軟性 & $.094^{*}$ \\
\hline \multicolumn{1}{c}{$R^{2}$} & $.348^{* *}$ \\
\hline${ }^{* *} p<.01 ;{ }^{*} p<.05$ &
\end{tabular}

*本研究では JSPS 科研費 24530799 の助成を受けた。 